\title{
Epidemiology of Different Types of Cancers Reported in Basra, Iraq
}

"Rafid A. Abood, ${ }^{1,2}$ Kareem A. Abdahmed, ${ }^{3}$ Seena S. Mazyed ${ }^{3}$

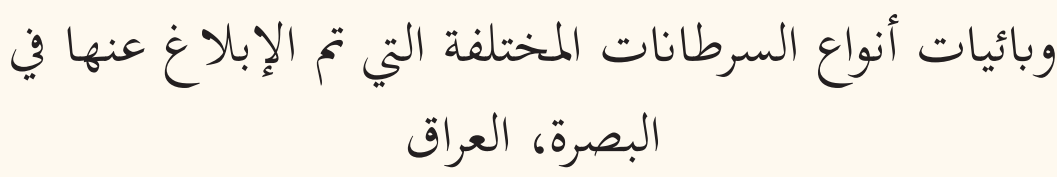

رافد عبود ، كريم عبد الأحمد ، سيناء مزيد

ABSTRACT: Objectives: This study aimed to report the incidence and pattern of various types of cancers and their distribution across various demographic groups in Basra, Iraq. Methods: Cancer cases recorded during 2017 at the Basra Cancer Control Centre, the Department of Pathology and Forensic Medicine, the Basra Oncology and Hematology Centre, the Basra Children's Hospital and at private laboratories were included in the study. Patients' records were analysed for information related to age, gender, residence and type of cancer. Incidences for different geographical regions and distribution of incidences across age groups were recorded as percentages. The mean age was recorded for patients of different genders and age groups. Incidence rates per 100,000 were calculated for different types of cancer. Results: A total of 2,163 cancer cases were identified of which 2,020 were in adults (93.4\%) and 143 were in children (6.6\%). Among adults, most cancers were found in females (59\%). Patients' mean age at diagnosis was $51.4 \pm 19.6$ years for adults and $6.4 \pm 4.23$ years for children. Cancer incidence rates per 100,000 people increased with age. Breast cancer was the most frequent cancer type found in adult females, with an incidence rate of 60.64 per 100,000 people. The most common types of cancer found in adult males were urinary bladder and lung and bronchus cancers; leukaemia was the most common cancer in children. Conclusion: The findings from this study can be used for predicting cancer epidemiology in Basra, Iraq, and to identify subsets of the population at high risk of cancer incidence. This information will help healthcare providers to adequately respond to the demands of diagnosis, treatment and palliative care for such patients.

Keywords: Neoplasms; Incidence; Epidemiology; Demography; Iraq.

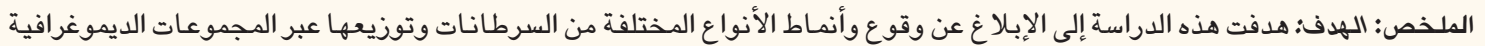

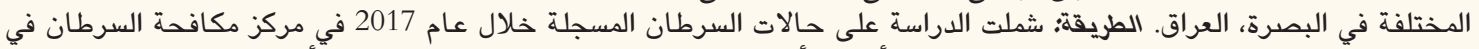

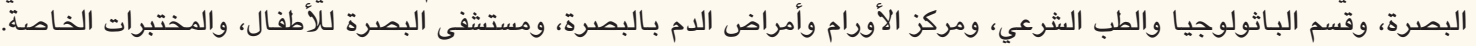

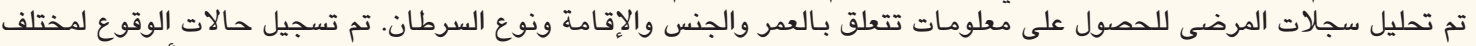

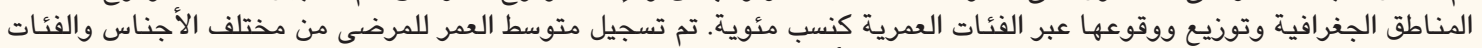

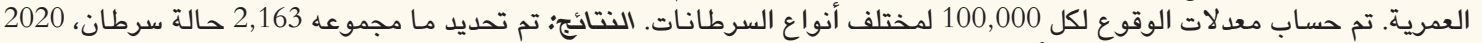

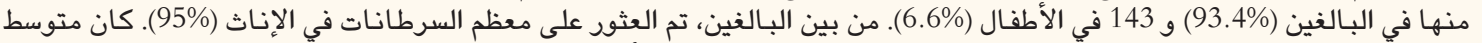

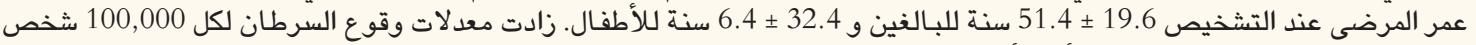

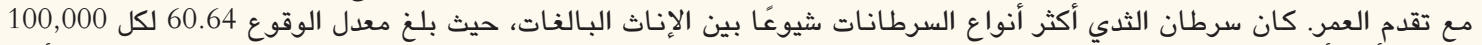

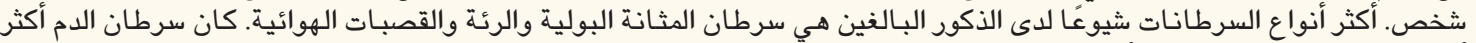

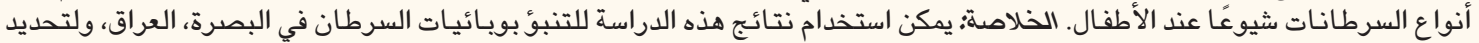

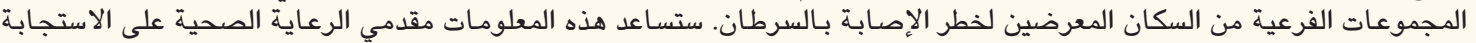

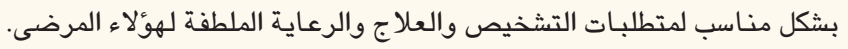
الكلمات المفتاحية: الأورام؛ وقوع؛ الويائيات؛ الديموغرافيا؛ العراق.

\footnotetext{
Advances in Knowledge

This epidemiological study provides the incidence of various types of cancer in adult (males and females) and in children in the Basra Governorate of Iraq.

The most frequent cancer types in males in Basra, Iraq are cancer of bladder, cancer of lung and bronchus, and lymphoma.

The most frequent cancer types in females in Basra, Iraq are cancer of breast, lymphoma, and cancer of ovary.

The most frequent cancer types among children in Basra, Iraq are leukemia, cancer of brain/CNS, and lymphoma.
} 
Application to Patient Care:

Epidemiological knowledge helps to understand the current burden of disease.

Future studies about incidence of cancer can help to identify the trends of increasing/decreasing incidences in each cancer types in each gender/age group

This information is also helpful for policymakers to devise strategies to combat cancer by formulating national programs.

\section{$\mathrm{T}$} he incidence of various cancers is increasing globally and is predicted to rise from 14.1 million new cases in 2012 to 20 million new cases in 2025. ${ }^{1}$ The proportion of cancer-related deaths increased from $14 \%$ in 2005 to $16 \%$ in $2015{ }^{2,3}$ With around 8.8 million global deaths in 2015, cancer has been recognised as the second leading cause of death after cardiovascular disease worldwide. ${ }^{3}$ Various studies predicted around 18.1 million new cancer cases and 9.6 million cancer deaths would be recorded globally in 2018. ${ }^{4}$ It was further estimated that in 2018, nearly $50 \%$ of all new cancer cases and over $50 \%$ of all cancer deaths would occur in Asia. ${ }^{4}$

Regional variations in cancer epidemiology have been well documented and are attributable to societal, economic and lifestyle changes across different regions. ${ }^{4}$ Although incidence, survival and mortality rates have been reported in many populations, very little is known about cancer incidence specifically in Iraq. ${ }^{6,7}$ Basra, located in the southern part of Iraq, has witnessed an increase in its cancer incidence and mortality rates since $2005 .{ }^{8}$ Therefore, this study aimed to determine the incidence rates and gender distribution of various cancers in the Basra Governorate of Iraq using epidemiological analysis.

\section{Methods}

This observational, cancer-registry-based study analysed all malignant cancer cases diagnosed from 1 January to 31 December 2017 in Basra, Iraq. The Basra Cancer Registry (BCR) was initiated in 1992 and is maintained by the Basra Cancer Control Centre (BCCC). The BCR compiles cancer-related epidemiological information from all major hospitals (both public and private) in Basra, including Basra Oncology and Haematology Centre, Basra Children's Hospital and the Basra College of Medicine. The BCR also compiles data from early detection centres, forensic medicine departments and all private laboratories including histopathology or haematology.

Data was collected through active monthly visits to the above-mentioned sites and a passive review from the $\mathrm{BCR}$ records of the $\mathrm{BCCC}$ because, according to a Basra Health Directorate decision, cancer notification has been mandatory since 2008. The collected data included demographic information (name, gender, age, address and nationality) and tumour details (diagnosis date, primary site and histology). Cases reported from governorates other than Basra were excluded from the study. Anonymised data of all cases from the Basra Governorate were computerised using the CanReg-3 programme (International Association of Cancer Registries, Lyon, France). Using the programme's modules, duplicate entries of the same cancer case were removed and verified cases were analysed.

The cancer incidence in populations of different age groups and of both genders was calculated. Patients' ages at time of diagnosis were recorded and the average age and incidence rates of different types of cancer were calculated for adults. Adults were defined as patients aged $\geq 15$ years and children were defined as patients aged $<15$ years.

The institutional ethics committee of College of Medicine, University of Basra, Iraq granted approval for this study.

\section{Results}

A total of 2,579 cases of cancer were recorded, of which 416 patients were excluded because they were not residents of Basra Governorate. The final total sample size was 2,163. Cancers were confirmed through histology/cytology ( $\mathrm{n}=1,910 ; 88.3 \%)$, haematology $(\mathrm{n}=102,4.7 \%)$, radiology $(\mathrm{n}=102 ; 4.7 \%)$, clinically $(\mathrm{n}=26 ; 1.2 \%)$ and by autopsy $(\mathrm{n}=11 ; 0.5 \%)$. For the remaining $12(0.6 \%)$ cases, the method of diagnosis was unknown.

The vast majority of cancer cases $(n=2,020$; 93.4\%) were recorded in adults while the remaining (n

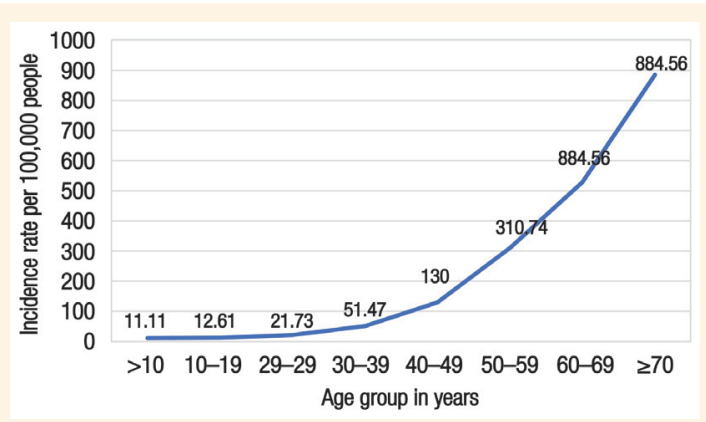

Figure 1: Incidence rate of cancer per 100,000 people across different age groups in Basra, Iraq in 2017. 
Table 1: Distribution of cancer incidence and incidence rate per population of 100,000 across different age groups in Basra, Iraq in $2017(\mathrm{~N}=2,163)$

$\begin{array}{lccc}\begin{array}{l}\text { Age group } \\ \text { in years }\end{array} & \mathbf{n}(\%) & \text { Population } & \begin{array}{c}\text { Incidence rate per } \\ \mathbf{1 0 0 , 0 0 0} \text { people }\end{array} \\ >10 & 97(4.5) & 873,046 & 11.1 \\ 10-19 & 85(3.9) & 673,993 & 12.6 \\ 20-29 & 109(5.0) & 501,563 & 21.7 \\ 30-39 & 205(9.5) & 398,226 & 51.5 \\ 40-49 & 366(16.9) & 281,546 & 130.0 \\ 50-59 & 442(20.4) & 142,241 & 310.7 \\ 60-69 & 475(22.0) & 89,846 & 528.7 \\ \geq 70 & 384(17.8) & 43,411 & 884.6 \\ \text { Total } & 2,163 & 3,003,872 & 72.0 \\ & (100) & & \end{array}$

Table 2: Frequency of occurrence and incidence rates per 100,000 people for the 10 most frequent types of cancer in the total adult population of the Basra, Iraq in 2017

$\begin{array}{lcc}\text { Type of cancer } & \mathbf{n}(\%) & \begin{array}{c}\text { Incidence rate per } \\ \mathbf{1 0 0 , 0 0 0} \text { adults }\end{array} \\ \text { Breast } & 559(27.7) & 31.0 \\ \text { Lymphoma } & 144(7.1) & 8.0 \\ \text { Lung and bronchus } & 132(6.5) & 7.3 \\ \text { Urinary bladder } & 127(6.3) & 7.0 \\ \text { Colorectal } & 118(5.8) & 6.5 \\ \text { Leukaemia } & 84(4.2) & 4.7 \\ \text { Unknown primary } & 76(3.8) & 4.2 \\ \text { Prostate } & 63(3.1) & 3.5 \\ \text { Ovary and stomach } & 61(3.0) & 3.4 \\ \text { Brain/CNS } & 59(2.9) & 3.3 \\ \text { Total (n = 2,020) } & 1,423 & 79.0 \\ \text { CNS central nervous system. } & & \end{array}$

Table 3: Frequency of occurrence of the 10 most frequent types of cancer and incidence rate per 100,000 children below the age of 15 years in Basra, Iraq in 2017

$\begin{array}{lll}\text { Type of cancer } & \mathbf{n}(\%) & \begin{array}{l}\text { Incidence rate per } \\ \mathbf{1 0 0 , 0 0 0} \text { children }\end{array} \\ \text { Leukaemia } & 56(39.2) & 4.7 \\ \text { Brain/CNS } & 24(16.8) & 2.0 \\ \text { Lymphoma } & 14(9.8) & 1.2 \\ \text { Bone } & 12(8.4) & 1.0 \\ \text { Soft tissue } & 9(6.3) & 0.7 \\ \text { Kidney } & 7(4.9) & 0.6 \\ \text { Neuroblastoma } & 7(4.9) & 0.6 \\ \text { Other BM disorders } & 4(2.8) & 0.3 \\ \text { Eye } & 3(2.1) & 0.2 \\ \text { Liver } & 2(1.4) & 0.2 \\ \text { Total (n = 143) } & 138(96.5) & 11.5 \\ \text { CNS = central nervous system; } B M=\text { bone marrow. }\end{array}$

$=143 ; 6.6 \%)$ were in children. The mean age of patients was $52.4 \pm 15.2$ years for adults and $6.4 \pm 4.23$ years for children. In adults, the mean age at the time of diagnosis was higher in males $(57.7 \pm 16.7$ years $)$ than females $(51.4 \pm 19.6$ years $)$. The incidence rate was 72/100,000 people [Figure 1]. The age-standardised rate was 129.82 . The cancer incidence rate per 100,000 people was highest among patients aged $>70$ years and $42 \%$ of the cases diagnosed in 2017 were $50-69$ years old [Table 1].

Breast cancer was the most common type of cancer among adults in Basra, constituting 27.67\% of the total cases diagnosed in 2017 with an incidence rate of 31.01 per 100,000 people. The five most frequent cancers (breast cancer, lymphoma, lung and bronchus cancer, urinary bladder cancer and colorectal cancer) constituted $53.47 \%$ of all cancer cases in Basra [Table 2]. In children, leukaemia was the commonest type of cancer recorded (4.66/100,000 children; 39.2\%), followed by cancers of the brain/ central nervous system (2/100,000 children; $16.8 \%$; CNS), lymphoma (1.16/100,000 children; 9.8\%) and bone cancer (1/100,000 children; 8.4\%) [Table 3].

Of the 2,020 cancer cases in adults, there was slight female preponderance with 1,191 (59\%) cases in females versus 829 (41\%) cases in males, yielding a male-to-female ratio of $1: 1.43$. In adult males, urinary bladder cancer was the most common type, representing $11.94 \%$ of cancers, followed by lung and bronchus cancer (10.86\%), lymphoma (8.56\%) and colorectal cancers $(8.44 \%)$. In adult females, breast cancer was the most common representing $45.42 \%$ of cancers, followed by lymphoma (6.13\%), ovarian cancer (5.12\%) and uterine cancer (4.21\%). The frequency of cancers affecting various organs varied between genders [Figure 2].

\section{Discussion}

Annual numbers of deaths worldwide due to cancer exceeds the total number of deaths attributed to tuberculosis, malaria and HIV/AIDS combined. ${ }^{9}$ Approximately $75 \%$ of total cancer deaths occur in low- and middle-income countries (LMICs). ${ }^{10}$ Cancer incidence in these countries is increasing rapidly due to changing demographics and increased exposure to various risk factors. ${ }^{10}$

The present study reports the epidemiology of various cancers in Basra, Iraq, during 2017. The cancer incidence rate in 2017 (72/100,000 people) increased by over 30\% from 2005 (54.26/100,000 people) ${ }^{8}$ More broadly, the Eastern Mediterranean region has witnessed a marked increase in cancer 
Table 4: Frequency of occurrence and incidence rate per 100,000 adult males/females of the 10 most frequent types of cancer in adult males and females in Basra, Iraq in 2017

$\begin{array}{lccccc}\begin{array}{l}\text { Type of cancer in } \\ \text { adult males }\end{array} & \mathbf{n}(\%) & \begin{array}{c}\text { Incidence rate } \\ \text { per } \mathbf{1 0 0 , 0 0 0} \text { adult } \\ \text { males }\end{array} & \begin{array}{c}\text { Type of cancer in } \\ \text { adult females }\end{array} & \text { n (\%) } & \begin{array}{c}\text { Incidence rate } \\ \text { per 100,000 adult } \\ \text { females }\end{array} \\ \text { Urinary bladder } & 99(11.9) & 10.9 & \text { Breast } & 541(45.4) & 60.6 \\ \text { Lung and bronchus } & 90(10.9) & 10.0 & \text { Lymphoma } & 73(6.1) & 8.2 \\ \text { Lymphoma } & 71(8.6) & 7.8 & \text { Ovary } & 61(5.1) & 6.8 \\ \text { Colorectal } & 70(8.4) & 7.7 & \text { Uterus } & 50(4.2) & 5.6 \\ \text { Prostate } & 63(7.6) & 7.0 & \text { Colorectal } & 49(4.1) & 5.5 \\ \text { Leukaemia } & 41(4.9) & 4.5 & \text { Leukaemia } & 43(3.6) & 4.8 \\ \text { Stomach } & 37(4.5) & 4.1 & \text { Lung and bronchus } & 42(3.5) & 4.7 \\ \text { Kidney } & 36(4.3) & 4.0 & \text { Unknown primary } & 41(3.4) & 4.6 \\ \text { Unknown primary } & 35(4.2) & 3.8 & \text { Cervix } & 31(2.6) & 3.5 \\ \text { Brain and CNS } & 31(3.7) & 3.4 & \text { Brain and CNS, } & 29(2.4) & 3.3 \\ \text { Total (n = 829) } & 573(69.1) & 63.0 & \text { thyroid } & & 107.6\end{array}$

CNS = central nervous system

\section{A}

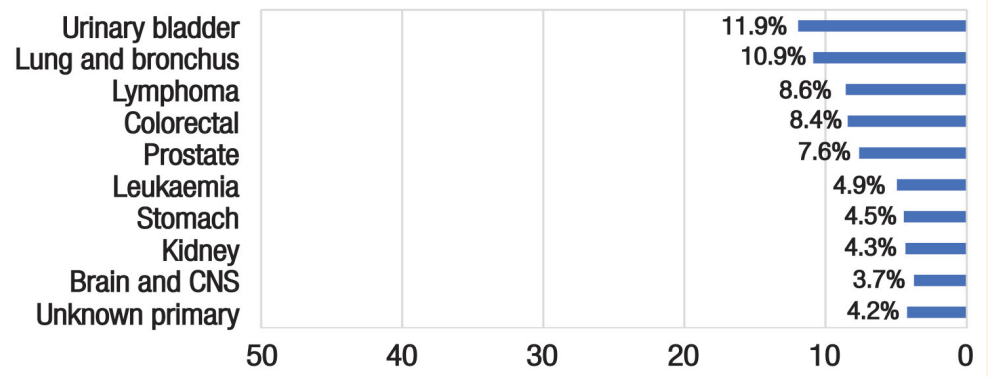

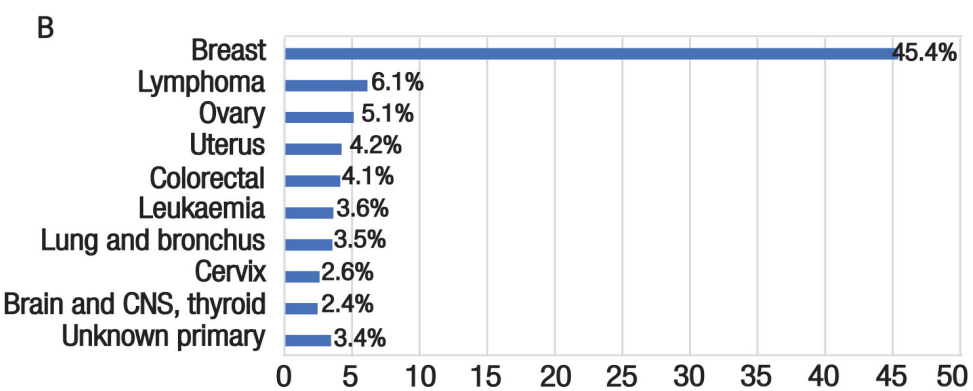

Figure 2: Frequency of occurrence of different types of cancer in adult males (A) and females (B) in Basra, Iraq, in 2017. CNS = central nervous system.

incidence from 494,690 in 2005 to 722,646 in 2015, although the increment of increase varies depending on countries' economic status. ${ }^{12}$ For example, the rate of increase was moderate in low-income countries such as Afghanistan (47.2\%), Djibouti (49.4\%), Somalia (67.6\%) and Yemen (49.4\%). A similar pattern was also recorded in middle-income countries such as Egypt (40.6\%), Jordan (54.1\%), Lebanon (78.2\%), Morocco (45.3\%), Pakistan (44.6\%) and Sudan (44.7\%). By contrast, the cancer incidence increased drastically in high-income countries such as Kuwait (79.6\%), Oman (123.9\%), Saudi Arabia (67.6\%) and the United Arab Emirates (182.9\%; UAE). ${ }^{12}$

Gender distribution in cancer incidence is an important aspect of cancer epidemiology. In Western countries such as the USA, UK and Europe, cancer affects males more than females. ${ }^{13,14}$ In contrast, in Middle Eastern countries, cancer affects females more than males, as observed in the current study as well as previous studies that focused on different parts of Iraq, 
and the Eastern Mediterranean region, including the UAE and Kuwait. $6,15,16$

Breast cancer represents approximately $45 \%$ of all cancer types in LMICs. ${ }^{17}$ Reflecting this observation, the current study found that breast cancer was the commonest cancer in Basra in 2017. Similar findings have been reported from Europe and the USA where the most frequent cancers as of 2018 in females was breast cancer, followed by cancers affecting the colorectal region and the lungs and bronchus. ${ }^{18}$ The incidence rate of breast cancer in the current study was found to be $60.64 / 100,000$ adult females, which is similar to findings reported in Egypt $(49.6 / 100,000)$, Jordan $(38.0 / 100,000)$ and Israel $(36.7 / 100,000)$ but lower than rates reported in the Western world (97.2/100,000 females in the USA). ${ }^{17}$ In Arab countries, the incidence rate of breast cancer is increasing rapidly due to rapid industrialisation and both delayed and reduced fertility. ${ }^{19}$ Other contributing risk factors leading to the increasing incidence of breast cancer in Arab countries include obesity, family history, hormonal therapy, post-menopause status, lack of education and no history of breastfeeding. ${ }^{20}$ Breast cancer was also reported to have the highest incidence rate in females in Sulaymaniyah, Iraq, between 2006$2014 .^{21}$ Similar to findings of the current study, AlJanabi et al. reported high incidence rates of breast, thyroid and colorectal cancers in females of Karbala, Iraq. ${ }^{6}$

The current study found urinary bladder cancer to be the most frequent cancer among Iraqi males, affecting $11.94 \%$ of the males in the study with an incidence rate of $10.88 / 100,000$ males. Across the world, urinary bladder cancer is the seventh most common type of cancer diagnosed in males. ${ }^{23}$ Various cities of Iraq have witnessed high rates of urinary bladder cancer, accounting for nearly $13-15 \%$ of total cases of cancer. ${ }^{24}$ The high incidence and mortality of bladder cancer in the Middle East has also been previously reported..$^{25}$ The reason for the high incidence of bladder cancer in Iraq needs to be further explored.

In comparison to the current findings, the incidence rates of lung cancer, leukaemia and lymphoma reported in males in Sulaymaniyah, Iraq, between 2006-2014 were 7.12, 4.5 and 4.32 per 100,000 people, respectively. ${ }^{21}$ Prostate cancer was the fifth most common cancer among males in the current study. In contrast, prostate cancer has been reported as the most frequent cancer amongst males in the USA and Europe according to the World Health Organization's (WHO) 2018 GLOBOCAN data. ${ }^{26,27}$ One possible explanation for the seemingly lower incidence of prostate cancer among Iraqi males is the overdiagnosis of prostate cancer in men in Europe and USA due to prostate specific antigen screening which is perhaps less observed in Iraq. Future studies are warranted to identify other factors contributing to this observed difference in epidemiology between males from Iraq and the Western world.

In this study, the commonest childhood cancer was leukaemia followed by brain/CNS cancers and lymphomas (39.2\%, $16.8 \%$ and $9.8 \%$, respectively). In Basra between 2012-2016, the incidences of these three cancers were $35.4 \%, 11.9 \%$ and $17.8 \%$, respectively. Even in Iran's Golestan Province in 2010, a similar pattern was reported..$^{28}$ The three most frequent childhood cancers were leukaemia (41.7\%), lymphoma (11.5\%) and brain and CNS cancers $(10.1 \%) .^{28}$

A major limitation of the current study is that, as this was a hospital-based registry, the calculated cancer incidence might not be as accurate as a population-based cancer registry. However, hospitalbased cancer registries have value as tools for policy formulations and region-specific data creation, especially in resource-poor regions. ${ }^{29}$ At present, the International Association of Cancer Registries-backed national cancer registry is involved in generating national-level cancer incidence rates in coordination with the WHO's GLOBOCAN project. ${ }^{30}$ To the best of the authosrs' knowledge, a population-based cancer registry does not exist which caters exclusively to the population of Basra. The data from this study can contribute to a more accurate estimation of cancer epidemiology in Iraq. The numbers obtained from the various sources were reported descriptively so do not statistically predict the future incidence of cancer in Basra. The heavy focus on the epidemiological aspects of cancer resulted in not collecting data pertaining to factors influencing cancer such as smoking habits, social and economic status, marital status and the presence of comorbidities.

\section{Conclusion}

In the current study, a hospital-based cancer registry was analysed for trends in cancer incidence in Basra, Iraq, in 2017. Breast cancer was the most frequent cancer type among adults and adult females, and urinary bladder cancer and leukaemia were the most frequent cancer types among adult males and children, respectively. This epidemiological study could be used as a tool to identify cancer risks and plan accordingly.

\section{CONFLICT OF INTEREST}

The authors declare no conflicts of interest. 


\section{FUNDING}

No funding was received for this study.

\section{References}

1. Ferlay J, Soerjomataram I, Dikshit R, Eser S, Mathers C, Rebelo $\mathrm{M}$, et al. Cancer incidence and mortality worldwide: Sources, methods and major patterns in GLOBOCAN 2012. Int J Cancer 2015; 136:E359-86. https://doi.org/10.1002/ijc.29210.

2. Global Burden of Disease Cancer Collaboration, Fitzmaurice C, Allen C, Barber RM, Barregard L, Bhutta ZA, et al. Global, regional, and national cancer incidence, mortality, years of life lost, years lived with disability, and disability-adjusted life-years for 32 cancer groups, 1990 to 2015: A systematic analysis for the Global Burden of Disease Study. JAMA Oncol 2017; 3:524-48. https://doi.org/10.1001/jamaoncol.2016.5688.

3. GBD 2015 Mortality and Causes of Death Collaborators. Global, regional, and national life expectancy, all-cause mortality, and cause-specific mortality for 249 causes of death, 1980-2015: A systematic analysis for the Global Burden of Disease Study 2015. Lancet 2016; 388:1459-544. https://doi.org/10.1016/ S0140-6736(16)31012-1.

4. Bray F, Ferlay J, Soeriomataram I, Siegel RL, Torre LA, Jemal A. Global cancer statistics 2018: GLOBOCAN estimates of incidence and mortality worldwide for 36 cancers in 185 countries. CA Cancer J Clin 2018; 68:394-424. https://doi.org/10.3322/ caac. 21492.

5. Global Burden of Disease Cancer Collaboration, Fitzmaurice C, Dicker D, Pain A, Hamavid H, Moradi-Lakeh M, et al. The Global Burden of Cancer 2013. JAMA Oncol 2015; 1:505-27. https://doi.org/10.1001/jamaoncol.2015.0735.

6. Al-Janabi AAHS, Naseer ZH, Hamody TA. Epidemiological study of cancers in Iraq-Karbala from 2008 to 2015. Int J Med Res Heal Sci 2017; 6:79-86.

7. Al-Asadi JN, Ibrahim SI. Childhood cancer in Basrah, Iraq during 2012-2016: Incidence and mortality. Asian Pac J Cancer Prev 2018; 19:2337-41. https://doi.org/10.22034/APJCP.20 18.19.8.2337.

8. Habib OS, Al-Ali JK, Al-Wiswasi MK, Ajeel NA, Al-Asady OG, Khalaf AA, et al. Cancer registration in Basrah 2005: Preliminary results. Asian Pac J Cancer Prev 2007; 8:187-90.

9. Prager GW, Braga S, Bystricky B, Qvortrup C, Criscitiello C, Esin E, et al. Global cancer control: Responding to the growing burden, rising costs and inequalities in access. ESMO Open 2018; 3:e000285. https://doi.org/10.1136/esmoopen-2017-000285.

10. Farmer P, Frenk J, Knaul FM, Shulman LN, Alleyne G, Armstrong L, et al. Expansion of cancer care and control in countries of low and middle income: A call to action. Lancet 2010; 376:1186-93. https://doi.org/10.1016/S0140-6736(10)61152-X.

11. The IQVIA Institute for Human Data Science. Medicines use and spending in the U.S.: A review of 2016 and outlook to 2021. From: www.iqvia.com/institute/reports/medicines-use-andspending-in-the-us-a-review-of-2016 Accessed: Feb 2020.

12. GBD 2015 Eastern Mediterranean Region Cancer Collaborators. Burden of cancer in the Eastern Mediterranean Region, 20052015: Findings from the Global Burden of Disease 2015 Study. Int J Public Health 2018; 63:151-64. https://doi.org/10.1007/ s00038-017-0999-9.

13. Siegel R, Naishadham D, Jemal A. Cancer statistics, 2012. CA Cancer J Clin 2012; 62:10-29. https://doi.org/10.3322/ caac. 20138 .
14. Wang Y, Freemantle N, Nazareth I, Hunt K. Gender differences in survival and the use of primary care prior to diagnosis of three cancers: An analysis of routinely collected UK general practice data. PLoS One 2014; 9:e101562. https://doi.org/10.1371/ journal.pone.0101562.

15. Kulhánová I, Bray F, Fadhil I, Al-Zahrani AS, El-Basmy A, Anwar WA, et al. Profile of cancer in the Eastern Mediterranean region: The need for action. Cancer Epidemiol 2017; 47:125-32. https://doi.org/10.1016/j.canep.2017.01.009.

16. Alwan N, Kerr D. Cancer control in war-torn Iraq. Lancet Oncol 2018; 19:291-2. https://doi.org/10.1016/S1470-2045(18)30135-9.

17. Tfayli A, Temraz S, Abou Mrad R, Shamseddine A. Breast cancer in low- and middle-income countries: An emerging and challenging epidemic. J Oncol 2010; 2010:490631. https://doi. org/10.1155/2010/490631.

18. Siegel RL, Miller KD, Jemal A. Cancer statistics, 2018. CA Cancer J Clin 2018; 68:7-30. https://doi.org/10.3322/caac.21442.

19. S Habib O, A Hameed L, A Ajeel N, Al-Hawaz MH, Al-Faddagh ZA, N Nasr G, et al. Epidemiology of breast cancer among females in Basrah. Asian Pac J Cancer Prev 2016; 17:191-5. https://doi. org/10.7314/apjcp.2016.17.s3.191.

20. Hamadeh RR, Borgan SM, Sibai AM. Cancer research in the Arab world: A review of publications from seven countries between 2000-2013. Sultan Qaboos Univ Med J 2017; 17:e147-54. https://doi.org/10.18295/squmj.2016.17.02.003.

21. Khoshnaw N, Mohammed HA, Abdullah DA. Patterns of cancer in Kurdistan - Results of eight years cancer registration in Sulaymaniyah Province-Kurdistan-Iraq. Asian Pac J Cancer Prev 2015; 16:8525-31. https://doi.org/10.7314/apjcp.2015.16.1 8.8525.

22. Centre for Arab Genomics Studies. Bladder cancer. From: www.cags.org.ae/ctga/details.aspx?id=748 Accessed: Feb 2020.

23. Zhang Y. Understanding the gender disparity in bladder cancer risk: The impact of sex hormones and liver on bladder susceptibility to carcinogens. J Environ Sci Health C Environ Carcinog Ecotoxicol Rev 2013; 31:287-304. https://doi.org/10 $.1080 / 10590501.2013 .844755$

24. Al-Fouadi A, Parkin DM. Cancer in Iraq: Seven years' data from the Baghdad Tumour Registry. Int J Cancer 1984; 34:207-13. https://doi.org/10.1002/ijc.2910340211.

25. Steliarova-Foucher E, Colombet M, Ries LAG, Moreno F, Dolya A, Bray F, et al. International incidence of childhood cancer, 2001-10: A population-based registry study. Lancet Oncol 2017; 18:719-31. https://doi.org/10.1016/S1470-2045(17)30186-9.

26. World Health Organisation. GLOBOCAN 2018. United States of America. From: https://gco.iarc.fr/today/data/factsheets/ populations/840-united-states-of-america-fact-sheets.pdf Accessed: Feb 2020.

27. World Health Organisation. GLOBOCAN 2018. Europe. From: https://gco.iarc.fr/today/data/factsheets/populations/908europe-fact-sheets.pdf Accessed: Feb 2020.

28. Moradi A, SemnaniS, RoshandelG, MirbehbehaniN, Keshtkar A, Aarabi M, et al. Incidence of childhood cancers in Golestan province of Iran. Iran J Pediatr 2010; 20:335-42.

29. Rajaram S, Bhaskaran S, Sinha S, Agarwal S. Role of hospitalbased cancer registries: A decade of experience of cancer cervix from a tertiary care centre, India. Indian J Community Med 2014; 39:241-4. https://doi.org/10.4103/0970-0218.143028.

30. World Health Organisation. Iraqi cancer data for 2017-2018 announced. From: www.emro.who.int/irq/iraq-news/cancerdata-for-20172018-announced-in-iraq.html Accessed: Feb 2020. 